\title{
Спин-зависимое туннелирование в гетероструктурах с магнитным слоем ${ }^{1}$
}

\author{
(C) К.С. Денисов ${ }^{1,2}$, И.В. Рожанский ${ }^{1,2}$, Н.С. Аверкиев ${ }^{1}$, E. Lähderanta ${ }^{2}$ \\ ${ }^{1}$ Физико-технический институт им. А.Ф. Иоффе Российской академии наук, \\ 194021 Санкт-Петербург, Россия \\ ${ }^{2}$ Lappeenranta University of Technology, \\ Fl-53851 Lappeenranta, Finland \\ E-mail: denisokonstantin@gmail.com
}

(Получена 25 апреля 2016 г. Принята к печати 25 апреля 2016 г.)

Предложен механизм создания спиновой поляризации в полупроводниковых гетероструктурах, содержащих квантовую яму и пространственно отделенный от нее слой магнитных примесей. Спиновая поляризация носителей заряда в квантовой яме появляется вследствие спин-зависимой туннельной рекомбинации на примесных состояниях в магнитном слое, при этом возникает быстрый линейный рост степени циркулярной поляризации фотолюминесценции из квантовой ямы. Теоретически рассмотрены две ситуации. В первом случае имеет место резонансное туннелирование на спин-расщепленные подуровни примесного центра, при этом генерация спиновой поляризации происходит в меру разной заселенности резонансных уровней в квантовой яме для противоположных проекций спина. Второй, нерезонансный случай, имеет место, когда спин-расщепленный примесный уровень лежит выше заполненных состояний электронов в квантовой яме и играет роль промежуточного состояния в двухэтапном когерентном процессе спин-зависимой рекомбинации электрона из квантовой ямы с дыркой в примесном слое. Разработанная теория позволила качественно и количественно объяснить кинетику фотовозбужденных электронов в экспериментах по фотолюминесценции с временны́м разрешением в гетероструктурах на основе InGaAs, легированных слоем Mn.

DOI: $10.21883 / \mathrm{ftp} .2016 .12 .44035 .8291$

\footnotetext{
${ }^{1}$ Полный текст этой статьи будет опубликован в журнале „Физика и техника полупроводников“, том 51 вып. 1.
} 